\title{
Research on the Performance and Enlightenment of New York Storm Surge Adaptive Landscape Infrastructure
}

\author{
Lu Feng ${ }^{1, *}$ \\ ${ }^{1}$ East China University of Science and Technology, School of Art, Design and Media, Shanghai, China
}

\begin{abstract}
In the context of global warming, the study of the resilient city and resilient landscape has received more and more attention. In this work, New York is used as an example to explore the practical applications of storm surge adaptive landscape infrastructure. The vulnerability of New York in storm surges and New York's plans for resilient city construction are introduced. Then according to the spatial distribution, through field research, questionnaires and data integration, the landscape infrastructure cases of beaches, waterfront parks, inland parks, nature areas and streets are studied, and their performance in Sandy is analysed. After that, under the guidance of resilient city theories and storm surge adaptation strategies, the experience that can be learned from these cases is summarized.
\end{abstract}

\section{Introduction}

From a global perspective, from 1880 to 2012 , the global average surface temperature of water and land increased by $0.85^{\circ} \mathrm{C}$, and the 30 years from 1983 to 2012 was the hottest 30 years in the Northern Hemisphere in the past 1400 years. From 1901 to 2010, the global average sea level rise reached 0.19 meters. From the mid-19th century, sea level rise was much larger than in the past 2000 years [1]. In the next few hundred years or even thousands of years, the global average temperature will rise by 1-4 degrees Celsius, causing sea level rise of 4-6 meters. The IPCC 2014 study shows that since the 1970s, the world has experienced longer-term and more destructive storm surges, which are consistent with global warming and rising sea levels. According to the model, if the global warming trend remains unchanged, the incidence of storm surge will increase by $66 \%$ in the future, which will bring greater threats.

As a low-lying estuary city, New York has always faced a severe storm surge problem, so there is no shortage of research and practice on storm surge adaptive landscape infrastructure. In 2012, New York suffered the greatest damage from Hurricane Sandy in the history. The arrival of Sandy is a realistic test of these landscape infrastructures, but some successful experience can also be obtained by analyzing its performance in the storm. Through the study of the completed projects in New York, the feasibility of adaptive landscape infrastructure under the theory of resilient city can be tested and the theories can be supplemented and revised in combination with the actual situation.

\section{New York and the Storm Surges}

\subsection{Storm surge history in New York}

New York is located in a storm-prone area. Since 1900, New York has suffered 14 hurricanes and numerous Nor'easters attacks (Table 1). The geographically formed "New York Bight" of New York and New Jersey's coastline happens to be a suitable angle, often causing sea storms to shift to New York and magnify its destructive power.

Due to the coincidence with the astronomical tide and the landing position in New York and New Jersey, on October 29, 2012, the most devastating super hurricane Sandy occurred in the New York area, causing an area of 132 square kilometres to be flooded, which accounts for $17 \%$ of New York's area. Forty-three people were killed, 1.1 million children were forced to suspend classes for a week, 2 million people lost power, and \$19 billion in economic losses [2].

Table 1. Storms through New York history

\begin{tabular}{|l|l|l|l|l|l|}
\hline & Name & Type & Speed & $\begin{array}{l}\text { Maximum } \\
\text { storm-high } \\
\text { tide level }\end{array}$ & Death \\
\hline 1821 & & Hurricane & $75 \mathrm{mph}$ & $4.0 \mathrm{~m}$ & \\
\hline 1838 & $\begin{array}{l}\text { Long } \\
\text { Island } \\
\text { Express }\end{array}$ & Hurricane & $100 \mathrm{mph}$ & & 10 \\
\hline 1964 & Carol & Hurricane & $100 \mathrm{mph}$ & & \\
\hline 1955 & $\begin{array}{l}\text { Connie \& } \\
\text { Diane }\end{array}$ & Hurricane & & & \\
\hline 1960 & Donna & Hurricane & $90 \mathrm{mph}$ & $3.4 \mathrm{~m}$ & \\
\hline 1972 & Agnes & Hurricane & & & \\
\hline 1976 & Belle & Hurricane & & & \\
\hline 1985 & Gloria & Hurricane & & & \\
\hline 1992 & Nor'easter & Nor' & & & \\
\hline 1995 & Felix & Hurricane & & & \\
\hline 1996 & Bertha & Hurricane & & & \\
\hline
\end{tabular}

\footnotetext{
* Corresponding author: fenglubjfu@163.com
} 


\begin{tabular}{|l|l|l|l|l|l|}
\hline 1996 & Edouard & Hurricane & & & \\
\hline 1999 & Floyd & Hurricane & $60 \mathrm{mph}$ & & \\
\hline 2003 & Isabel & Hurricane & & & \\
\hline 2006 & Ernesto & Hurricane & & & \\
\hline 2007 & Nor'easter & $\begin{array}{l}\text { Nor' } \\
\text { easters }\end{array}$ & & & \\
\hline 2011 & Lee & Hurricane & $65 \mathrm{mph}$ & & \\
\hline 2011 & Irene & Hurricane & & & \\
\hline 2012 & Sandy & Hurricane & $85 \mathrm{mph}$ & $2.9 \mathrm{~m}$ & 43 \\
\hline
\end{tabular}

\subsection{Vulnerability of New York in current facing storm surge}

Before Sandy, New York had been using the floodplain map drawn by the Federal Emergency Management Agency (FEMA) in 1983. But the area that flooded during Sandy was much larger than the map defined. So, in 2013, combined with Sandy's disaster situation, a new map of the floodplain was updated by FEMA. The map shows that the flooding area is 49.6 million square meters (an increase of $42 \%$ over the 1983 edition), and 67,700 buildings in the city are in the floodplain (an increase of $90 \%$ over the 1983 edition). In Manhattan, Brooklyn and Queens, approximately 400,000 residents live in the floodplain (up 83\%) (Figure 1). The population live in New York floodplain is the largest compared with other storm-stricken cities' in the United States (Table 2). It can be seen that New York has been very vulnerable to the threat from storm surge.

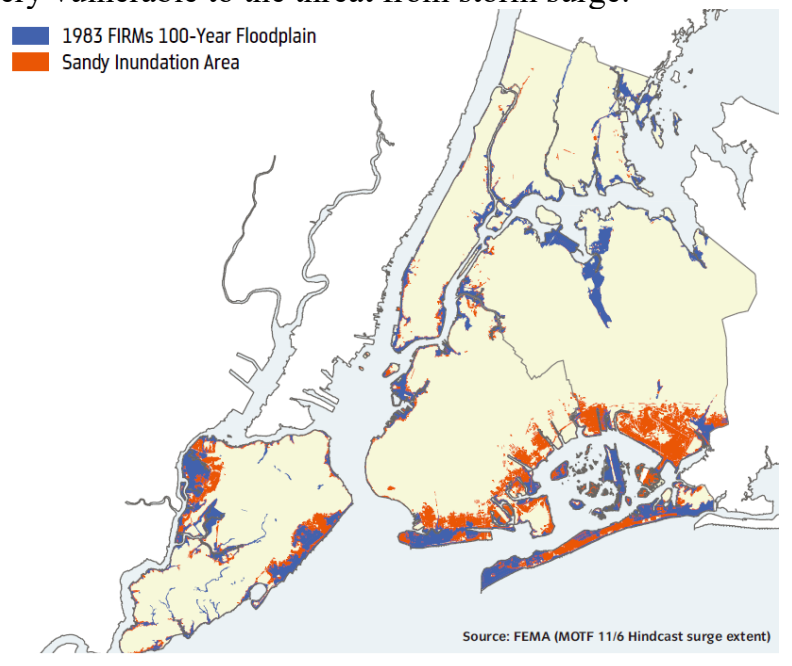

Fig. 1. 1982 FEMA FIRMs and Sandy Inundation Area Comparison (Credit: FEMA)

Table 2. Floodplain comparison of major American cities.

\begin{tabular}{|c|c|c|c|c|}
\hline City & $\begin{array}{c}\text { Populatio } \\
\text { n in the } \\
100 \text {-year } \\
\text { floodplain }\end{array}$ & $\begin{array}{c}\text { Share of } \\
\text { total } \\
\text { populati } \\
\text { on }\end{array}$ & $\begin{array}{c}\text { Land area } \\
\text { of 100- } \\
\text { year } \\
\text { floodplain } \\
\text { (square } \\
\text { Miles) }\end{array}$ & $\begin{array}{c}\text { Population } \\
\text { density of } \\
\text { 100-year } \\
\text { floodplain } \\
\text { (people per } \\
\text { square mile) }\end{array}$ \\
\hline $\begin{array}{c}\text { New } \\
\text { York }\end{array}$ & 398,100 & $5 \%$ & 48 & 8,300 \\
\hline $\begin{array}{c}\text { Hou } \\
\text { ston }\end{array}$ & 296,400 & $14 \%$ & 107 & 2,800 \\
\hline $\begin{array}{c}\text { New } \\
\text { Orle } \\
\text { ans }\end{array}$ & 240,200 & $70 \%$ & 183 & 1,300 \\
\hline
\end{tabular}

\begin{tabular}{|c|c|c|c|c|}
\hline $\begin{array}{c}\text { Mia } \\
\text { mi }\end{array}$ & 144,500 & $36 \%$ & 18 & 8,000 \\
\hline $\begin{array}{c}\text { Fort } \\
\text { Lau } \\
\text { derd } \\
\text { ale }\end{array}$ & 83,200 & $50 \%$ & 21 & 4,000 \\
\hline $\begin{array}{c}\text { San } \\
\text { Fran } \\
\text { cisc } \\
\text { o }\end{array}$ & 9,600 & $1 \%$ & 3 & 3,200 \\
\hline
\end{tabular}

\subsection{Vulnerability of New York facing future storm surge}

New York City Panel on Climate Change (NPCC) was established in 2008 to conduct research related to the New York area. In the 2013 NPCC report, New York will face greater disasters caused by climate change in the future. For example, by the middle of this century, as the rate of melting of polar glaciers increased, the sea level in New York would rise by 0.76 meters, causing a five-fold increase in the frequency of 100-year storm surges. In addition, New York will also experience more frequent and greater rainfall, and the incidence of heat waves will triple. At the same time, New York also promoted the cooperation between NPCC and FEMA to map the floodplain. The new map shows that in 2020, the flood flooding area will increase by 153 square kilometers (23\% increase), including 88,800 buildings (an increase of $31 \%$ ). By 2050, the 100-year flood floodplain will increase by 186 square kilometers, accounting for about $24 \%$ of the urban area (Figure 2). This includes 114,00 buildings, $97 \%$ of urban power facilities, and $20 \%$ of medical facilities. It can be seen that New York is showing greater vulnerability in the future.

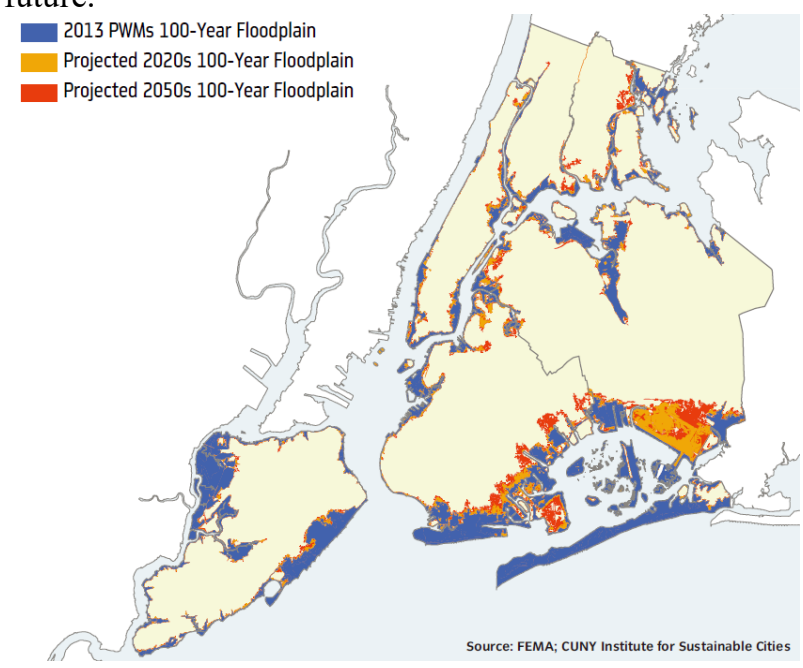

Fig. 2. New York Projected Inundation Map (Credit: FEMA)

\section{The performance of New York landscape infrastructure during Sandy}

Landscape infrastructure includes both natural wetlands, forests and artificial parks and green spaces; small to a garden and large to the landscape planning for an area. In the city, the landscape as an infrastructure penetrates 
all aspects of the city, such as transportation, recreation, water conservancy, stormwater management, and agricultural production. So, landscape infrastructure plays an important role in the adaptation of urban storm surge and is an important part of resilient city. For the convenience of research, the landscape infrastructures that are most closely related to storm surge adaptation are divided into the following sections by space.

\subsection{Waterfront parks}

In 2007, New York began the PlaNYC program to explore the adaptive strategies of resilient city. Vision 2020 - The New York city comprehensive waterfront plan released by the New York city department of urban planning in 2011 is a guiding strategy to improve water bank resilience in response to climate change and sea level rise. The urban waterfront adaptation strategy released in 2013 and the Post-Sandy waterfront conference held by the Metropolitan Waterfront Alliance in the same year both made the important work of increasing the resilience of the waterfront parks. Today, 209 kilometers of New York's waterfront are parks, protected areas and other open spaces. Since 2002, nearly half of New York's waterfront areas have been converted into connected parks [3]. The design of the new waterfront parks is integrated into the storm surge adaptive strategies. In Sandy, Brooklyn Bridge Park, Bronx Waterfront Park, Hudson Waterfront Park are all successful cases. These parks provide us with valuable experience.

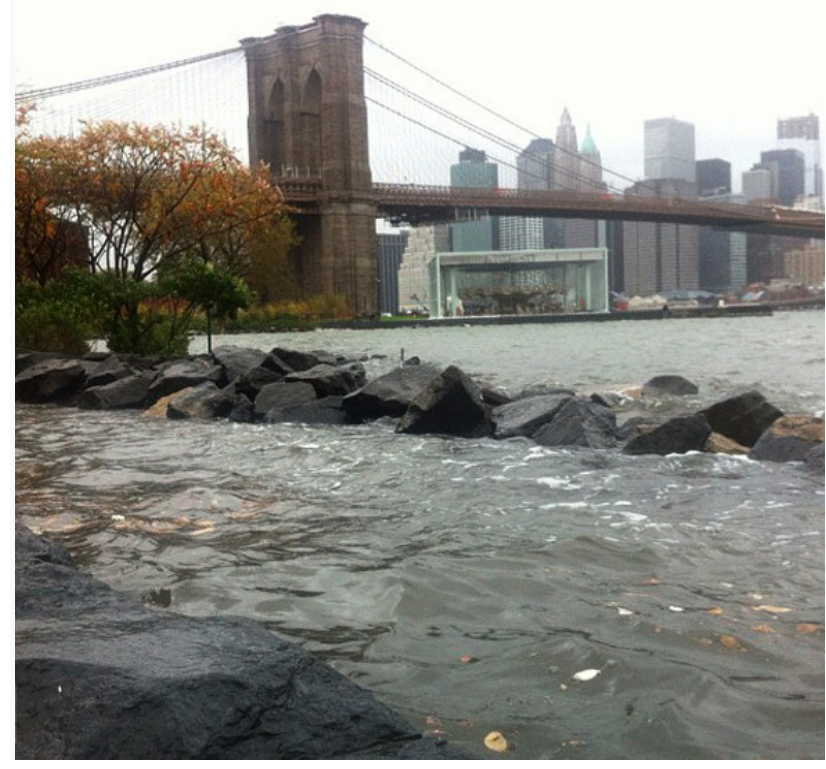

Fig. 3. Brooklyn Bridge Park during Sandy (Credit: Matt Danzico)

The Brooklyn Bridge Park underwent serious impact during Sandy. The lowland was flooded for up to four hours and the deepest water level reached 1.8 meters (Figure 3). The low-level power and mechanical facilities failed, and three newly planted trees collapsed. Some pavements at the South Terminal 6 were also deformed due to prolonged flooding. But the overall losses are limited to these. Compared with other city parks, Brooklyn Bridge Park has not been closed for a long time because of Sandy. And this is due to its advance consideration of climate change and sea level rise in the design phase and a series of resilient measures were taken. 1) In terms of topography, according to the 100-year floodplain map in New York, the overall terrain of the park was raised and the pier 1 was even raised 9.1 meters. In addition, according to the rising sea level of 2.4 meters in 2045, the planting height of the plant roots has been increased to 2.4 meters or more [4]. Compared with the surrounding waterfront parks that have not been raised, the degree of damage is minimized. 2) In terms of vegetation, the choice of plants in the park varies according to the topography and the distance from the water bank. In general, the park chooses local salttolerant plants such as Prunus maritime, Pinus rigida, Baccharis and the like. In addition, plants have also been used as measures to consolidate shorelines. For example, the salt marsh wetlands in the West Pier 1 have utilized the Spartina alterniflora that once flourished on the southeast coast of the United States to slow the wave impact. 3) In terms of revetment, most of the vertical revetment was changed to a riprap shore. Compared with the traditional vertical revetment, the gaps between the riprap gravel can allow the seawater to pass through, so the direct impact force is smaller. The multi-layered gravel absorbs the impact force in a geometrical order. So the riprap is not easy to destroy and is more stable. In addition, the salt marsh wetland and the reinforced pier columns also played a role in buffering the wave impact. 4) In terms of material, locally recycled materials are widely used. Long-leaf yellow pine is known for its good ductility and corrosion resistance. The wood recovered from the original cold storage in Pier 1 was used to build park chairs, paving and so on. While the granite is hard and wear-resistant, the park's granite is mostly taken from bridges demolished elsewhere in New York. The Brooklyn Bridge Park, which uses local materials, has not been more damaged than the coastal walkway made of tropically-imported timber on Rockaway Beach. 5) In terms of facility, Brooklyn Bridge Park has an advanced stormwater management system. $70 \%$ of the irrigation in the park is from the collection of rainwater and the recycled park water [5]. The ground drain channel and the underground retention filter system (Figure 4) can quickly and effectively remove ground water and filter it, which plays a good role in Sandy. 6) In terms of operation, Brooklyn Bridge Park adopts a new selfsustaining economic model. $10 \%$ of the park area is used to develop housing and commercial houses, 438 apartments and 6,700 square meters of commercial space are built [6]. In return, the park's construction and maintenance funds will be provided from the park maintenance fee paid by the tax from the apartment owner, and the developer's sales income. After the disaster, with the guidance of the Park Development Committee and the support of the residents and through rapid financial response, the staff methodically eliminated the malfunctions, repaired the site, and the park was reopened only five days after the disaster. 


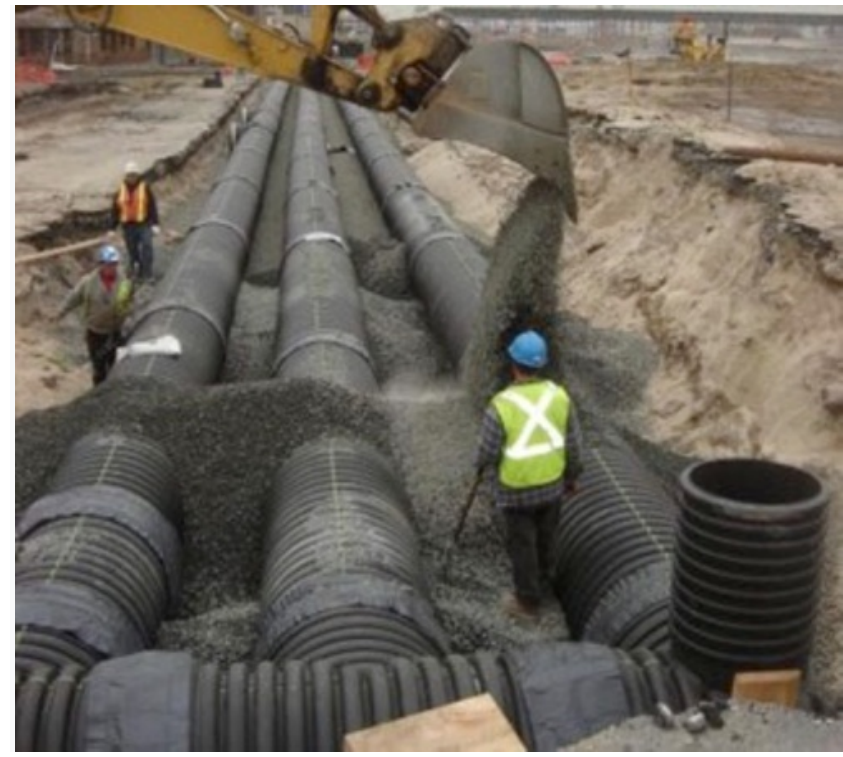

Fig. 4. Water retention and Filtration System (Credit: Julienne Schaer)

\subsection{Inner land parks}

New York has 1,942 parks, more than 1,000 playgrounds, more than 800 athletic fields, 550 tennis courts, 60 public pools and 30 recreation centers (Figure 5). Connecting these parks to one another and to the cities' waterfront and beaches are over $161 \mathrm{~km}$ of greenways that provide residents and visitors with pedestrian and cyclist-friendly corridors [7].

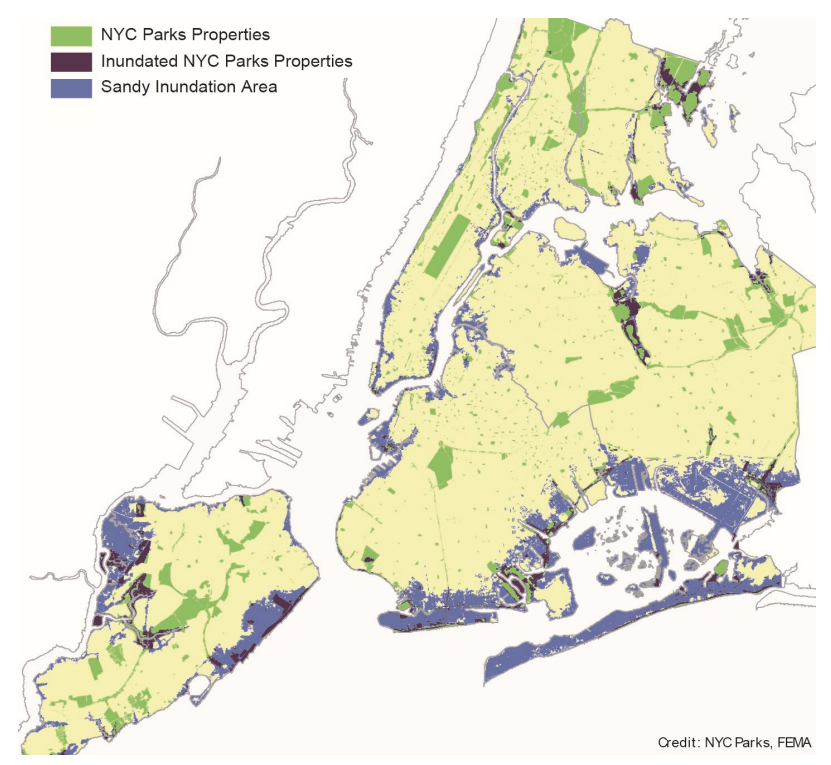

Fig. 5. Inundated Parks and Parks in Floodplain

In Sandy, although the inland parks were not directly impacted by the waves like the waterfront parks, they were also seriously damaged in the flooded area. For example, the Asser Levy Recreation Center, the Tony Dapolito Recreation Center, the Inwood Nature Center and the Red Hook Recreation Center have suffered from serious structural and mechanical conditions. The electricity system was destroyed and the filtration system of the outdoor pool was ineffective and forced to close for 4 weeks.

However, Sara D. Roosevelt Park in Manhattan, which assists in dispatching needed resources in emergency situations, was equipped with a generator and continued operation despite widespread power loss in surrounding areas. The park also provides temporary living space for the affected residents, such as providing temporary teaching places for the affected schools. According to the survey, $68 \%$ of New York residents believe that the biggest failure in landscape infrastructure facing the storm surge is the destruction of the facilities. Inland parks, due to their geographical advantages, are less affected by storm surges and can even serve as a supplement to surrounding facilities. This advantage can also be fully utilized in the storm surge adaptive landscape infrastructure construction.

\subsection{Beaches}

The beaches are the most direct places to receive storm surges and always suffer major damages. Sandy is most devastated on the beaches of the eastern and southern coasts of Staten Island, the Rockaway Peninsula, the island of Coney, and the southern part of Brooklyn. On the southern shore of Staten Island, 28,000 cubic meters of sand was lost and all wooden planks were destroyed. The Rockaway peninsula lost 2.3 million cubic meters of sand, and the entire wooden planks was destroyed. In some places, the coastline receded 21 meters [8]. Residents lost power, and residents of high-rise homes were trapped in apartments with water cuts, power outages, and no elevators. The fast track connected to New York on the Rockaway Peninsula stopped working for several months due to the damage to the brackets on Jamaica Bay.

Although the beaches in New York suffered such great damage, some beach conservation projects carried out by the government and residents before Sandy played a very good role. For example, Rockaway Beach in Queens, the Beachside Bungalow Preservation Association (BBPA) has launched a community-based dune construction and maintenance program. Salttolerant beach grasses, black pine trees and other shrubs were planted and maintained under the support of the New York Foundation and the JM Kaplan Foundation. Just a few months later, the beach grass has been covered with the entire sand dune. The beach grass has a root system of 1.5 meters deep, which can fix the sand dunes and promote the deposition of sand and gravel. After establishing the first dune system along the coastal boardwalk, BBPA, with the assistance of DPR and DEC, built a 1.8-meter-high dune on the outskirts of the existing dune and extend the beach grass in the northern dunes under the support of local residents (Fig. 6). Thanks to the rapid fertility of the beach grass and the help of bird-borne seeds, the new sand dunes quickly covered with beach grass, shrubs and trees. This new dune was turned into a sacrificial dune, forming a double dune system along with the original dunes on the 24 th to 
27th streets. In Sandy, the height of the waves at Far Rockaway reached 4.6 meters, and the sacrificial sand dunes from 26th to 27 th were almost completely destroyed. The original sand dunes from 24th Street to 26th Street in the north of the sacrificial dunes are preserved by the good vegetation coverage and protect the surrounding communities from flooding (Figure 628). It can be seen that the combination of arbor and shrub has a good effect on stabilizing the sand dunes (Fig. 7). The beach grass has a quick effect, which can help the sand dunes to deposit and enlarge the area, while the deep root woody plants can resist the strong wind and fix the sand dunes. The double dune system has a significant effect on weakening the wave impact. After sacrificing the first dune, the second dune can play a good role in protecting the surrounding communities.

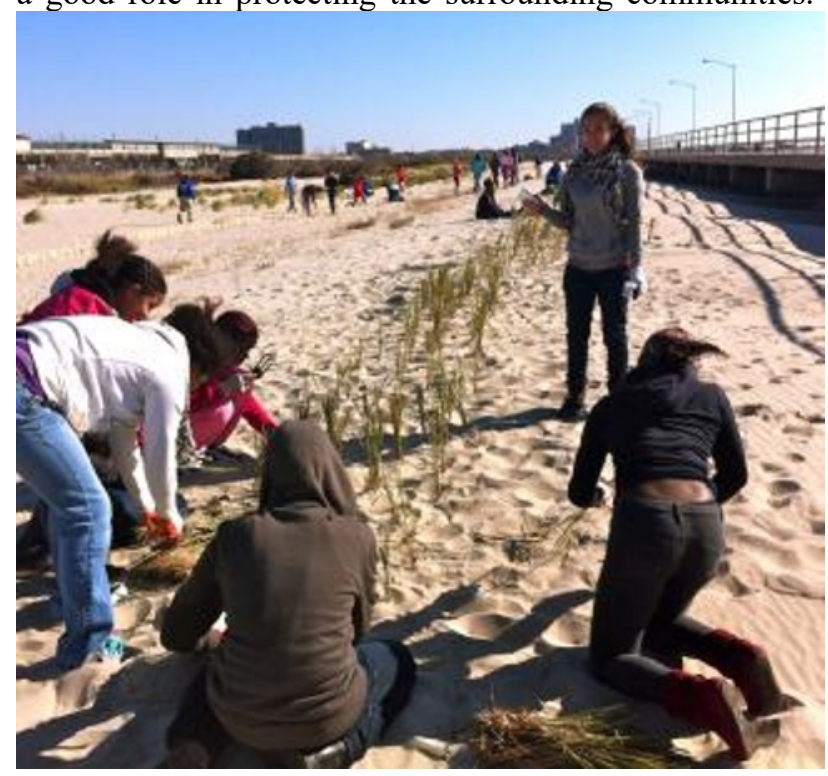

Fig. 6. Sand Grass Plantation by the Publics (Credit: BBPA)

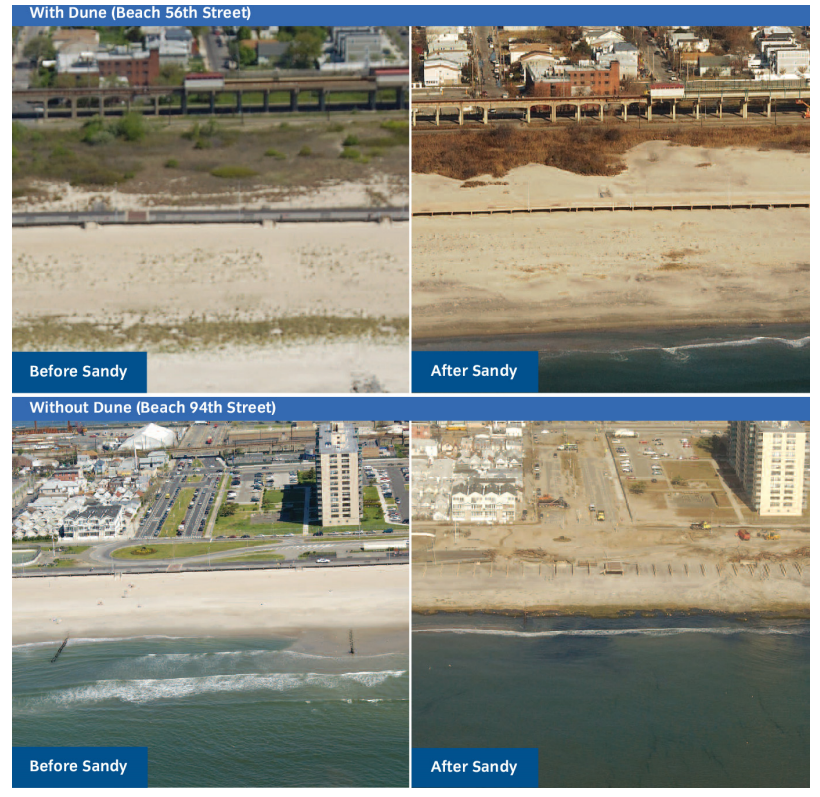

Fig. 7. Sand Dunes in Rockaway Peninsula (Credit: PlanNYC)

\subsection{Natural areas and preserves}

New York's natural habitat covers an area of 4,006 hectares, including forests, grasslands and wetlands, which account for one-third of New York's entire green space system (Figure 8). Natural areas provide many benefits, including air quality improvements, carbon sequestration, enhanced wildlife habitats, stormwater retention, shoreline protection, and native plant life preservation. Wetlands play an important role in storm surge defense due to their geographical location and unique composition.

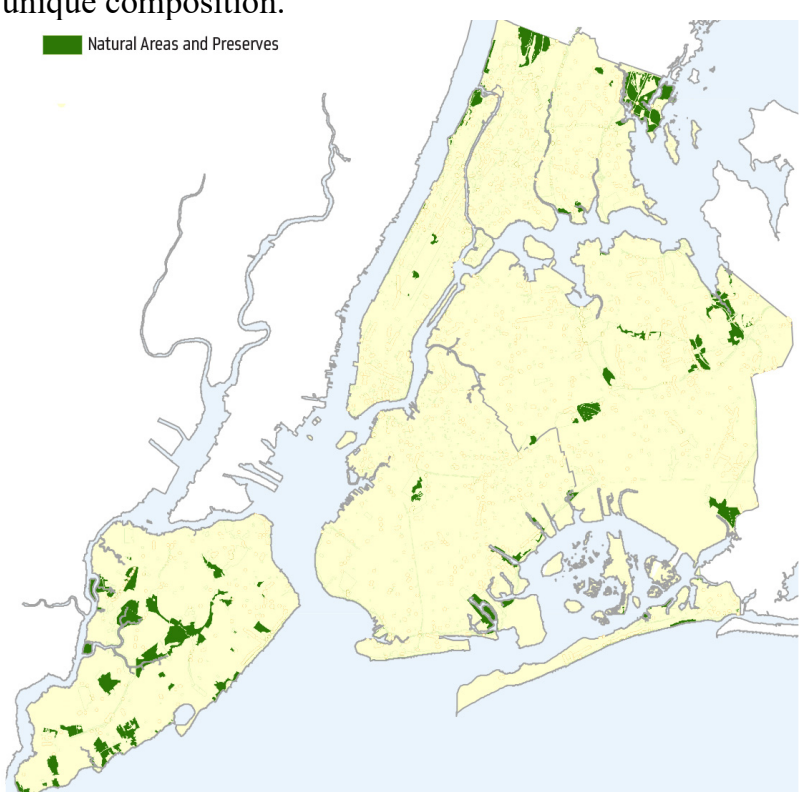

Fig. 8. New York's Natural Areas and Properties (Credit: DPR)

For example, the Gerritsen Creek is a freshwater stream located south of Brooklyn Marine Park and infused into Jamaica Bay. In 1950, the New York Department of Sanitation used the site for construction waste landfill, causing serious water pollution. In 2010, New York City and the US Army Corps of Engineers (USACE) jointly launched the restoration project for the Gerritsen Creek ecosystem. Completed in 2012, there were 7.2 hectares of tidal marshland, 9.3 hectares of rare coastal grassland and 8.1 hectares of wetlands been restored [9]. The Gerritsen Creek Ecosystem Restoration Project focuses on revitalizing its aquatic and coastal grassland environmental vigor. This includes restoring its original plant diversity, primarily through the purification of previously contaminated water bodies and the removal of invasive species. At the same time, the project also excavated construction waste and reshaped the environment to suit for wetland plants and grassland growth through the gentle slope. In Sandy, the slope of most salt marshes is higher than the height of the storm surge, so it acts as a good barrier and protects the surrounding communities. Because the wetland plants grow lush and thick, the storm surge couldn't cause serious damage, and the revetment at the edge of the wetland is also survived under the protection of plants. Before and after Sandy, the coastline around the wetlands, grasslands and woodlands in the Gerritsen Creek was not destroyed, and it was a successful and resilient case of artificially reserved natural area. 


\subsection{Green streets}

New York's Streets projects on landscape infrastructure include Greenstreets projects and the MillionTrees NYC program. The Greenstreet project was a joint project between NYC Department of Parks \& Recreation (DPR) and the NYC Department of Transportation (DOT) in 1996. Its original purpose is to beautify the city. Since 2008, green streets have integrated stormwater management into it, with a view to reducing the city's combined sewer overflow problem. Then in 2009, New York received the American Recovery and Reinvestment Act (ARRA) grant to build 28 streets with stormwater management capabilities. With the support of various departments, the New York Greenstreet project has been greatly developed. Green streets are also prominent in purifying the air, cooling down temperature, and providing habitat for animals and plants. The study found that every 0.4 hectares of green streets can trap 520 cubic meters of rainwater [10]. And with proper design, the trapped rainwater can be used for site storage and irrigation.

The MillionTrees NYC program (Figure 9) was launched in 2007 by DPR as part of the New York restoration program. Mayor Bloomberg also used it as part of plaNYC to plant one million trees in 2017. The project received strong support from all walks of life in New York (nearly 50,000 New Yorkers). The government planted $70 \%$ of the trees, and private organizations, community groups and individuals planted the remaining $30 \%$. The plan will increase forest coverage in New York by $20 \%$. This has played a huge role in purifying air, rainwater management, and lowering ground temperatures. In the selection of tree species, DPR has selected as many as 140 species of trees, and selected different tree species according to the lighting conditions and flooding risks of different sites, so as to improve the adaptability of trees to the site and increase their resiliency to different impacts.

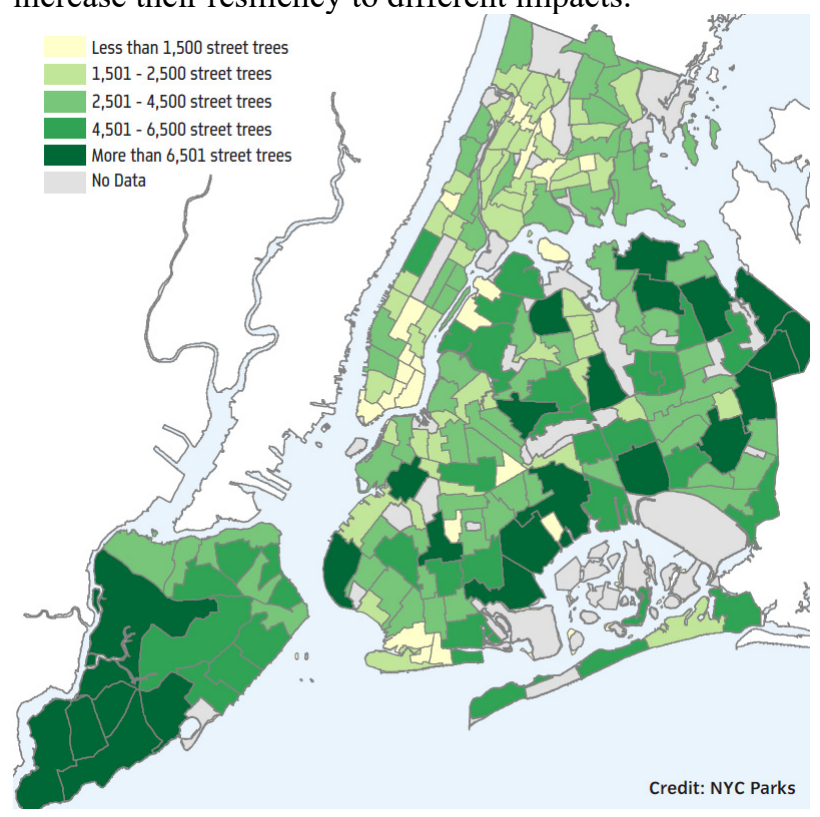

Fig. 9. NYC Street Trees Map

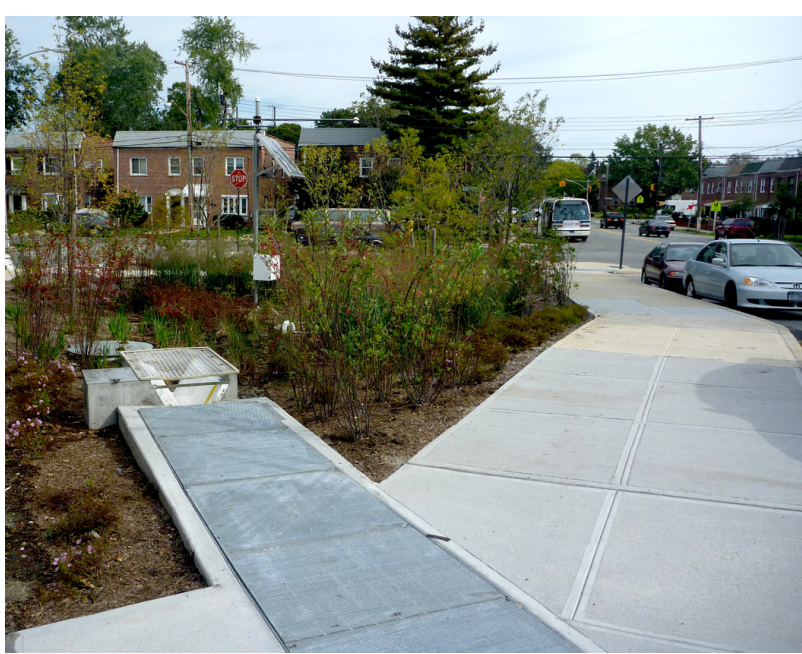

Fig. 10. Nashville Street (Credit: DPR)

In Sandy, the sensors installed on the green street Nashville Street (Figure 10) provided real-time monitoring of the amount of precipitation and the overflow into the site, and can show how much water seeps into the ground, how much water is evaporated or overflows into the surrounding detention tank. The data shows that the street has intercepted all rainfall and overflow from surrounding streets, and its catchment area has reached 31 times its own area, receiving 4.9 cubic meters of rainwater and 14.8 cubic meters of overflow from surrounding sites. Compared with regular streets, the interception capacity of the street has increased by $3,000 \%$ [11]. It can be seen that the green street performed very well in Sandy. The MillionTrees NYC program left a large number of trees in New York to intercept the rainwater through the leaves and slow down the speed of rainwater mixed into the sewage system. It also slowed down the wind speed and resisted the storm surge when the hurricane hit. Finally, in Sandy, New York lost only 11,000 street trees. The main disaster-affected species were some species that were rarely planted in New York in recent years, including Norway maple and silver. It shows that the choice of street trees in New York is relatively successful, and green streets have high resiliency in dealing with disasters.

\section{Experiences learned}

\subsection{Elevating topography has proven to be the most effective measure}

Whether it is pre-planned to raise the topography or afterward landscape transformation, the hills play a good role in defending the storm and protecting the surrounding communities. Therefore, the prediction of sea level rise and the prediction of urban floodplain are very important. The design needs to set important facilities above the waterline. As with the Brooklyn Bridge Park, it is a clever way to incorporate elevated terrain into the landscape and perform certain functions, 
so it can avoid the spatial fragmentation caused by the big height difference.

\subsection{Localized materials are more resilient}

New York emphasizes the recycling of materials in the construction of landscape infrastructure and therefore promotes the use of local materials. In fact, after a long evolutionary process, local materials are more adaptable to the local environment and perform better when the storm surge occurs. At present, many parks face serious homogenization problems, and ornamental horticultural plants are often the first choice, which happen to be the most fragile plant materials. If the storm surge can be considered in the design phase, the use of local resilient plants will greatly increase the protection ability of the waterfront park. The use of resilient local engineering materials can also significantly reduce disaster losses.

\subsection{Storm surge adaptive facilities do not conflict with daily use}

The mound system and sand dune system, which play a good defense role in Sandy, are not only a defensive project, but also can block noise, create interesting space and provide a place for activities. If we can integrate the disaster relief facilities into the landscape infrastructure that originally to be built, such as revetment and earthwork, then it is more labour-saving and economic effective than adding other protective measures after the park is completed. And they will not affect the daily use of the park. Due to storm surge adaptive design is still in its infancy worldwide, and has not attracted the attention of the government and developers. This maybe a good measure when there is insufficient funding to support storm surges adaptive projects.

\subsection{Self-sustaining market operating mechanism performs well}

Brooklyn Bridge Park provides a very successful model for the operation of waterfront park. At present, the domestic waterfront parks adopt the government unified construction management method. While the Brooklyn Bridge Park has not only become the driving method of surrounding real estate, but the real estate gain can also be directly used for the maintenance of the park. This kind of system is quick and effective, because the park is directly related to the income of real estate, so the operation and maintenance are also more attentive. In the event of a disaster, once a defect is discovered, it can be remedied more quickly, and more effective according to local conditions. Therefore, this is a more resilient waterfront park operation model, which is worth learning from.

\subsection{Sound laws and regulations provide institutional guarantees}

The United States is the first country in the world to establish a national mandatory flood insurance. The United States Congress enacted the National Flood Insurance Law as early as 1968. The US Federal Disaster Management Agency (FEMA) also mapped the flood insurance map, although it was not updated in time in Sandy, but provided the city with a reference to the floodplain, thus limiting the development area and different insurance to purchase. In addition, the United States implements a disaster grading management system, and the state government is the main responsibility unit, which improves the efficiency of regional joint defense. The state government is responsible for raising funds for the construction of disaster prevention infrastructure, the establishment of land management regulations and disaster forecasting work. In addition, on this basis, New York has enacted local laws, stipulating that urban new development zones must enforce "stagnation of water storage on the spot" and not allow any large buildings to be built near the estuary of the underground waterway. At the same time, flood insurance is also purchased for the low-income group.

\subsection{Greater public participation promotes the development of landscape infrastructure}

Public participation has a high level of recognition in New York. According to the survey, $85 \%$ of New Yorkers realize that Sandy is related to global climate change, and $71 \%$ realize that landscape infrastructure is important for storm surge defense. In the actual participation, $21 \%$ of people in New York have participated in volunteer activities such as landscape infrastructure construction and donations, and another $87 \%$ expressed their willingness to participate in the construction and maintenance of landscape infrastructure. For example, landfill park Fresh kills held 14 hearings and public meetings during the design and construction process from 2005 to 2011, so that the opinions of residents were reflected in the park. The public also played an indispensable role in the construction of sand dunes at Rockaway Beach. After Sandy, the New York public also actively cooperated with the government in disaster recovery. In addition, the government and related organizations are also committed to promoting public participation. For example, the New York Regional Plan Association (RPA) is a private research and planning agency that promotes public participation and promotes the collection of opinions through the TV program "Regional Goals". It can be seen that New York has a large public participation, which is an important source of strength for the development of landscape infrastructure outside the government.

\section{Conclusion}

This research begins with an overview of New York, and its vulnerability facing storm surges, and introduces New York's plans for resilient city. Then according to the 
spatial distribution, the paper introduces the landscape infrastructure of waterfront parks, inland parks, beaches, natural areas and green streets, then analyses the impact of Sandy on them and their performances. After that, under the guidance of resilient city theory and the storm surge adaptation strategy, the cases are summed up to present existing problems and lessons that can be learned.

This work is supported by Shanghai Chenguang Project (16CG72)

\section{References}

1. R.K. Pachauri, L.A. Meyer, Climate Change 2014: Synthesis Report. Contribution of Working Groups I, II and III to the Fifth Assessment Report of the Intergovernmental Panel on Climate Change [R]. Switzerland: IPCC, 2014: 42.

2. Federal Emergency Management Agency (FEMA), Sandy Overview. https://www.fema.gov/hurricanesandy-nfip-claims, 2015-2-4.

3. Department of City Planning City of New York, Vision 2020, New York City Comprehensive Waterfront Plan [R]. New York: DCP, 2011: 24.

4. Happold Consulting, Sandy Success Stories [R]. New York: Happold Consulting, 2013: 12.

5. R. McMackin. Weathering the Storm: Horticulture Management in Brooklyn Bridge Park in the Aftermath of Hurricane Sandy. http://www.ecolandscaping.org/01/stormwatermanagement/weathering-the-stormhorticulturemanagement-in-brooklyn-bridge-park-intheaftermath-of-hurricane-sandy, 2013-1-15.

6. Bruner Foundation, Ruby Bruner Award for Urban Excellence: Brooklyn Bridge Park [R]. New York: Bruner Foundation, 2011: 66.

7. Michael r. Bloomberg, A stronger, More Resilient New York [R]. New York: City of New York, 2013:192.

8. R. Platt. Impact of Superstorm Sandy on New York City's New Waterfront Parks, 6 (2013)

9. U.S. Army Corps of Engineers, Final Integrated Ecosystem Restoration Feasibility Report and Environmental Assessment [R]. New york, USACE, 2018: 85.

10. New York City Department of Parks \& Recreation (DPR). New York City's Urban Forest. http://www1.nyc.gov/nycresources/service/1780/greenstreets-program, 20162-2

11. New York City Department of Parks \& Recreation (DPR). MilliontreesNYC. http://www.milliontreesnyc.org/html/home/home.sht $\mathrm{ml}, 2013-5-18$ 